\title{
Peering over the edge of the short period? The Keynesian Roots of Stock-Flow Consistent Macroeconomic Models
}

Antonio Carlos Macedo e Silva ${ }^{1}$ and Cláudio H. Dos Santos ${ }^{2}$

Resumo: Este texto argumenta que modelos de "consistência entre fluxos e estoques" - i.e. modelos que identificam os agentes econômicos com as principais categorias sociais/setores institucionais, descrevem o comportamento desses agentes no curto prazo e tratam de forma consistente as implicações patrimoniais desses comportamentos "período a período" - são (i) perfeitamente compatíveis com empreendimentos intelectuais (teóricos ou históricos) inspirados na visão e nas teorias elaboradas por Keynes ao longo de toda sua carreira; (ii) a ferramenta teórica ideal para análises pós-keynesianas de médio prazo; e, portanto, (iii) cruciais para a afirmação do projeto de pesquisa pós-keynesiano mais amplo.

Palavras-chave: fluxos e estoques; análises macrodinâmicas; "Escola pós-keynesiana".

\begin{abstract}
This work argues that institutionally rich stock-flow consistent models - i.e. models in which economic agents are identified with the main social categories/institutional sectors of actual capitalist economies, the short period behavior of these agents is thoroughly described, and the "period by period" balance sheet dynamics implied by the latter is consistently modeled - are (i) perfectly compatible with Keynes' theoretical views; (ii) the ideal tool for rigorous Post Keynesian analyses of the medium run; and, therefore, (iii) crucial to the consolidation of the broad Post Keynesian research program.
\end{abstract}

Key words: stock-flow consistency; medium-run analyses; Post Keynesian macroeconomics. JEL Codes: B50; E12

Área Anpec: 1. Escolas do Pensamento Econômico, Metodologia e Economia Política

\footnotetext{
${ }^{1}$ Professor of Economics at the University of Campinas (UNICAMP), Brazil.

${ }^{2}$ Research scholar at the Levy Economics Institute of Bard College, USA and research economist at the Institute for Applied Economic Research (IPEA), Brazil.
} 


\title{
Peering over the edge of the short period? The Keynesian Roots of Stock-Flow Consistent Macroeconomic Models
}

"We have all of us become used to finding ourselves sometimes on the one side of the moon and sometimes on the other, without knowing what route or journey connects them, related, apparently, after the fashion of our waking and our dreaming lives" (Keynes, 1936)

\begin{abstract}
This work argues that institutionally rich stock-flow consistent models - i.e. models in which economic agents are identified with the main social categories/institutional sectors of actual capitalist economies, the short period behavior of these agents is thoroughly described, and the "period by period" balance sheet dynamics implied by the latter is consistently modeled - are (i) perfectly compatible with Keynes' theoretical views; (ii) the ideal tool for rigorous Post Keynesian analyses of the medium run; and, therefore, (iii) crucial to the consolidation of the broad Post Keynesian research program.
\end{abstract}

Key words: stock-flow consistency; medium-run analyses; Post Keynesian macroeconomics; JEL Codes: B50; E12

\section{Introduction}

Neoclassical economists tend to value the construction of models in which the free functioning of market forces generates a perfect "order" (or something close to that). This "optimum" order, according to most neoclassicals, would rule in the long run. ${ }^{3}$ Post Keynesian economists - particularly "American" Post Keynesians ${ }^{4}$ - radically reject this approach and tend to take refuge in short run models. Neoclassical economists are led to the ecstasy of an optimum world through parables "where somehow the future has already happened" (Robinson, 1979: xiii) and which supposedly provide them with ways to express normative judgments. Post Keynesians, for whom the neoclassical future is a mere illusion, frequently are resigned to living here and now; they are reluctant (or even refuse) to mobilize their typical institutional and historical knowledge to build models which aim to shed light on longer periods.

Caricatural as it is (but caricatures are interesting precisely because they accentuate elements of truth), the description above provides a context to this article. We aim to argue here that institutionally rich stock-flow consistent models - i.e. models which identify economic agents with the main social categories/institutional sectors of actual capitalist economies, thoroughly describe these agents' short period behaviors, and consistently model the "period by period" balance sheet dynamics implied by the latter - are (i) perfectly compatible with Keynes's own views on the macroeconomic dynamics of capitalist economies; (ii) the ideal tool for Post Keynesian analyses of the medium-run; and therefore, (iii) a crucial contribution to the consolidation of the broad Post Keynesian research program.

The remaining of this text is divided in six sections. The second section develops the caricature above, i.e. discusses the reasons why orthodox macroeconomists tend to emphasize the long run and Post Keynesians tend to emphasize the short run. The next three sections aim to stress the affinity between stock-flow consistent (SFC) models and the writings of Keynes. The third section discusses the central role played by agents' portfolio decisions in the determination of the Keynesian "short period equilibrium". The fourth section revisits the Tract on Monetary Reform (Keynes, 1923), in order to remind the reader of some of Keynes' views on the political economy of capitalism - particularly the importance given by Keynes to heterogeneities (especially of power; see Carvalho, 1992:45) among economic agents. Section 5 then discusses the main features of SFC models (and some of their idiosyncrasies) while the sixth section revisits the concept of "long period equilibrium" presented by Keynes in chapter 5 of the General Theory and shows how it can be re-interpreted to illuminate mediumrun macroeconomic analyses. Section 7 concludes the paper.

\footnotetext{
${ }^{3}$ Even if orthodox macroeconomists (especially new classical ones) often find it useful to assume that the markets work perfectly also in the short run.

${ }^{4}$ Which follow closely the works of Davidson (1972/1978) and Minsky (1975) and, therefore, emphasize the importance of the Knight/Keynes concept of radical uncertainty.
} 


\section{2 - Time and order in orthodoxy and heterodoxy}

Economics got its scientific identity and autonomy with the perception that the very large number of (decentralized) decisions taken by economic agents in historical time could result in a certain "order" (or "coherence"). This perception, which fascinated Smith as much as it stimulated Marx, goes through the history of the discipline, and is shared by orthodox and heterodox economists alike. However, economists have different (Schumpeterian) "visions" on the characteristics of that order. They also disagree on the relative merits of the strategies which have been used to study it.

The order may be more or less "perfect" and stable; it can be perceived as a creation of markets or as a result which depends also on other considerations (such as the role played by political institutions). For most economists the fascination with markets prevails. This fascination in its most extreme forms is mixed up with exaltation: markets are deemed the only acceptable mechanism to order production and the distribution of wealth; nothing can produce a better result than the one derived from the (almost) free operation of the "invisible hand."

But extreme views are not shared by most economists, not even by orthodox ones. Most orthodox economists (even those radically opposed to any activism by macroeconomic policy) are ready to admit that, in the "real world", the free operation of markets would yield sub-optimum results (at least in the short run).There are many explanations for that: agents make mistakes; markets are incomplete and/or imperfect; other (economic or not) institutions that help to assure coordination are absent or ineffective. This kind of perception, when linked to a more "activist" world view or to the belief that market failures can often be more costly than government failures, ${ }^{6}$ opens a field of research that aims at identifying suboptimum situations (for example, disequilibria in labor and/or credit markets) and at developing ways to improve on them through economic policies and/or institutional reforms. This is, of course, the quintessential orthodox Keynesian view, shared by both "old" and "new" Keynesians. 7,8

Within the neoclassical "citadel" (Keynes,1934: 489) there is strong disagreement on the relative importance of "market failures" and "government failures". But there is virtual unanimity about the usefulness of theoretical models in which market failures do not exist and the State is assumed away. These models are not built only to indulge economists' theoretical curiosity. On the contrary, they produce states or trajectories to which neoclassicals attribute great importance. As far as the neoclassical view is concerned, such models allow the analyst to transcend the "veil" imposed by the imperfections of the real world and reveal the "true" nature of an economy ruled by markets: the ability to generate an optimal order in which general equilibrium prevails. ${ }^{9}$

In macroeconomics - leaving aside the short-lived "civil war" waged by new classicals ${ }^{10}-$ the perfection of markets is generally assumed to hold in a hypothetical "long run", whose (vague and variable) meaning is hardly discussed. ${ }^{11}$ But how do the interactions between agents that in the short run bring about chronic unemployment, financial crises, recessions, booms, and structural changes of all sorts eventually produce the long run equilibrium? For the dominant orthodox view the answer to that question

\footnotetext{
${ }^{5}$ One has to keep in mind that the identification with the "laissez faire" is always a matter of degree. Even macroeconomists opposed to government intervention in the (macro) economy do recognize that the State has important roles in the provision of several public goods and in the development of mechanisms (such as "monetary and/or fiscal rules") to ensure the "good behavior of market forces".

${ }^{6}$ Of course, according to this interpretation, new classicals would be against activist macroeconomic policies simply because they believe that "government failures" have a higher social cost than "market failures".

${ }^{7}$ New Keynesians believe that most market failures can be corrected - even in the short run - as long as government intervention is "surgical" enough. Old Keynesians, in turn, see the negative effects of market failures as essentially inevitable in the short run, but believe that these effects do disappear in the long run (though at a great social cost).

${ }^{8}$ Heterodox Keynesians are activists, but not "imperfectionists": they do not explain the results produced by markets by the distance between the "real world" and an abstract (and "perfect") world in which neoclassical general equilibrium holds.

${ }^{9}$ In this sense, neoclassicals radicalize the classical tradition (of, say, Ricardo or Stuart Mill) in which market processes evolve so as to purge the relative "disorder" of the short run (market prices tend to "natural" prices; profit rates become even, etc).

${ }^{10}$ Whose models tend to assume that all markets always clear.

${ }^{11}$ For a perceptive taxonomy of the possible meanings of the "center of gravitation" metaphor, see Harcourt (1982).
} 
does not matter at all. ${ }^{12}$ Their objective is precisely to build trajectories in which the only dynamics is that of adjustment. In other words, mechanisms that can postpone or make the coming of neoclassical long run unfeasible, ${ }^{13}$ are assumed away as irrelevant. ${ }^{14}$ To announce the good news of the eternal optimal order produced by markets nothing better than a "parable" (in Solow's revealing expression, 1970/2000). A parable must be simple as well as "elegant". All that matters is that the prodigal son returns home and that his return is properly celebrated. His misbehaviors along the way are not particularly relevant. And, of course, it is unthinkable that he might get lost on the way back or that the house might no longer be there when he arrives. ${ }^{15}$

For Keynes, orthodox theory imposed on its followers the torments (and the delights) of an existence divided between the two incommunicable faces of the moon. On the one hand, the luminous face ruled by the "theory of value", in which money is neutral and prices are flexible, so as to assure long run general equilibrium. On the other hand, the thick mist of the short run, which is ruled by the "theory of money and prices", and in which all kinds of disequilibria are possible (Keynes, 1936:292). As Solow himself (1970/2000) recognizes, the route between the short run and the long run is still unknown. ${ }^{16}$

As a matter of fact, it is very difficult to find in the theoretical literature any effort to build explicit connections between the passage of time and optimality. ${ }^{17}$ Now, is it correct to state that neoclassical economists really believe that, as time goes by, individual rationality (or the "natural selection" through the markets as suggested by Friedman) is able to eliminate short run inefficiencies? Do they really expect that the economy will eventually adjust itself to an optimum state or trajectory? Maybe the mathematical precision of formal models has induced critics (and naïve practitioners) to a positive answer to both questions. In a less literal (and maybe more representative) interpretation the idea must be that, apart from "pathological" situations, ${ }^{18}$ the various kinds of shocks to which the economic system is routinely submitted are relatively "inconsequent" (or qualityless as in Carvalho, 1984/1985). In other words, they average to zero, causing only relatively small and brief deviations from the equilibrium path - so that the equilibrium configurations described by these models turn out to be close, on average, to observed figures.

If this is true, it is then reasonable (and not a mere act of faith) to assume that the message of the very simplified and abstract neoclassical long run parables is a decent approximation of reality. ${ }^{19}$ In other words, if the long run configuration described by neoclassical parables more or less correspond to the "stylized facts" gathered in empirical research, it would be possible to conclude that we live, more or less,

\footnotetext{
${ }^{12}$ Of course, there are exceptions. One of them, maybe surprisingly, is Solow himself (1970/2000: xiv) when he states that the "problem of combining long run and short run macroeconomics has not been solved yet". More than that, Solow regrets having removed from his articles on growth, which awarded him with the Nobel Prize, the problem of effective demand (id. Ibid)

${ }^{13}$ Examples are abundant. One of them is the way how Modigliani (1944) elegantly extracts from chapter 19 of the General Theory only the so-called "Keynes-effect", choosing to overlook all the other mechanisms (linked to income and wealth distribution and to expectations) that can disturb the relationship between prices and aggregated demand by which fullemployment is re-established. Another example is the postulation by Solow (1956) that price flexibility by itself allows one to neglect effective demand problems (and so of unemployment) during the convergence process to long run steady state (also see Solow, 1970/2000).

${ }^{14}$ Or better, they are irrelevant to economists studying long run configurations, but can be important to economists studying the timing and the social cost of the adjustment process (so as to eventually come up with normative proposals to make it more efficient).

${ }^{15}$ We do not ignore that several orthodox economists work with hysteresis models, and here again Solow (1999) comes to our minds, along with Blanchard and Summers (1988), Aghion and Banerjee (2006) and Acemoglu and Robinson (2007), among several others.

${ }^{16}$ Even more interestingly, Solow (1970/2000: xvii) recognizes that in several situations it becomes "impossible to believe that the equilibrium growth path itself is unaffected by the short-to medium-run experience". This is the reason for his warning, conveniently ignored in several contexts, that "the steady state is not a bad place for the theory of growth to start, but may be a dangerous place for it to end" (Solow, 1970/2000: 7).

${ }^{17}$ General equilibrium theorists are the first to recognize the dynamic instability of Walrasian equilibria (see Lavoie, 1992, chapter 1 and Ingrao and Israel, 1990).

${ }^{18}$ Blanchard (2007) refers to phenomena as depressions and hyper-inflations in this way.

19 "If it is too much to say that steady-state growth is the normal state of affairs in advanced capitalist economies, it is not too much to say that divergences from steady-state growth appear to be fairly small, casual, and hardly self-accentuating. You would not react to the sight of an economy in steady-state growth as you would react to the sight of a pendulum balanced upside-down, or a vacuum sitting in plain daylight while Nature abhors it" (Solow, 1970/2000: 10-11).
} 
in an optimum world. ${ }^{20}$ This perspective, which is not sufficient to soothe the more restless minds within the citadel, causes perplexity and repulse in heterodox headquarters. There is no better example of orthodox discomfort than Keynes' (1923) own in the Tract on Monetary Reform. In the famous boutade about the long run, Keynes does not question the existence of an optimal long period equilibrium. But he does question the efficiency of markets in promoting the convergence to this equilibrium. And, in so doing, he questions also the relevance of economists, ${ }^{21}$ challenged to come up with economic policies that avoid persistent (and maybe pathological) deviations from the equilibrium path. So, there is an evident similarity between the Keynes of the Tract and the Keynesians of the mainstream.

Now, for heterodox economists to infer the convergence to general equilibrium from the relative order of the economic world is not so different from taking the beauty of the sunset and the complexity of the human brain as evidences of the intelligent design. However, if the heterodox economists reject by unanimity the relation between order and optimality, they do not seem to agree on the nature of that order and on the best strategies to study it.

Many authors have surveyed heterodox Keynesianism, in more or less ecumenical ways. ${ }^{22}$ Given our aims in this article, Carvalho (1984-85) is particularly interesting, for he organizes the several "heterodox Keynesian schools" according to their respective views of the nature of the short and the long runs. More than that, he shows that the very object of economic reflection varies depending on each view.

A peculiar extreme would be occupied by Shackle, who questions the idea that the "human behavior can be modeled" (ibid, p.227) and, therefore, refutes the very possibility (or interest) of studying both long term and short-term configurations. ${ }^{23}$ On the other extreme, there would be economists who, as Kaldor in his famous 1956 article $^{24}$ and the neoricardians (such as Pasinetti and Garegnani), strongly invest in the study of (static or dynamic) "centres of gravitation" which supposedly would give coherence to the performance of long run economies. According to Carvalho (p.221),

"A common feature of all these gravity center theories is that one freely passes from definitions of abstract equilibrium conditions to descriptions of actual growth paths. The whole possible field of research regarding the relations between short and long run is completely ignored. This prevents the development of a complete theory of the gravitation process itself beyond the point of merely stating its necessity, which is especially obvious in the theory of investment".

Carvalho's critique seems to suggest a research program similar to the one we intend to describe and defend in this article. As we understand it, this program starts from the hypothesis that the short run is not only intelligible, but a solid foundation upon which one can build theories that (supported also by the facts of experience) dare to scrutinize "longer runs". ${ }^{25}$ In these theories short run events are not "qualityless", since they do affect the course of events. In other words, the proposal consists of exploring the "relations between short and long-terms" without the aprioristic resource to a (long run ${ }^{26}$ ) centre of gravitation, may it be optimum (as in the orthodoxy) or sub-optimum (as in the neoricardians). The

\footnotetext{
${ }^{20}$ This seems to be Arrow's (see Serrano,1995) and Solow's (1970/2000) interpretation. Textbooks are normally less careful: Mankiw: (1998:33) is satisfied with stating that the "basic hypothesis" of classical models - the flexibility of prices - "applies to the long run behavior of an economy". Blanchard (2007: 187) affirms that - "when we look back and examine the economical activity in longer periods (...) fluctuations disappear. Growth (...) becomes the dominant factor". Stiglitz and Walsh (2003: 119) believe that, "in the long run there are enough jobs for the ones who want to work".

21 "Economists set themselves too easy, too useless a task if in tempestuous seasons they can only tell us that when the storm is long past the ocean is flat again" (Keynes, 1923: 65).

${ }^{22}$ See, for example, Harcourt and Hamouda (1988), King (2002), Davidson (2003-4), Lavoie (2006) and Harcourt (2006), inter alia.

${ }^{23}$ But, for a less nihilistic rendition of Shackle, see Harcourt \& Sardoni (1995).

${ }^{24}$ That led Samuelson to dub him Jean Baptiste Kaldor (Harcourt, 1986). It seems to us quite unfair to classify Kaldor taking into account only this article.

${ }^{25}$ We distance ourselves here from neoricardians, for whom the short run is the kingdom of the circumstantial and the transitory and only the long run is really intelligible.

${ }^{26}$ We owe this qualification to Harcourt (1982). According to him, Keynes and Keynesian economists do subscribe $a$ notion of centre of gravitation when they assume (probably because this is not absurd in the real world) that the point of effective demand is at least somewhat robust (in "static" or "stationary" models, as Kregel, 1976, would have it) in face of falsified short-run expectations.
} 
suppression of the latter would not imply that "anything is possible", given that "limitations emerge in the form of institutions and interrelations" (Carvalho, 1984/85: 224).

But how does one carry on such a research program in practice? Carvalho discards Kalecki's formal models for being too "mechanistic" - in the sense that they artificially separate short and long run phenomena. ${ }^{27}$ What is left is the "fourth way", defended by Carvalho and by the "American Post Keynesians" such as Davidson, Kregel and Minsky. ${ }^{28}$

According to Carvalho, in the American Post Keynesian tradition the subject of analysis is radically changed "( ...) from long-run positions to long run expectations" (p.225). This proposition only reinforces, of course, the familiar Keynesian hypothesis according to which investment is the "causa causans" (Keynes, 1937: 121) of macroeconomic dynamics. The problem with this position, as we see it, is that it makes the study of the latter topic quite difficult. We do, of course, find in the American Post Keynesians a crystal clear description of the complexities associated with investment decisions in conditions of radical uncertainty - due to the non-ergodic nature of the economic environment (Davidson, 1982-83). We also find the development of Keynes' seminal insight that radical uncertainty fosters the appearance of "conventions" between the agents that, together with other institutions (such as wage contracts and the State), help to "anchor" the agents' expectations (Davidson, 1972/1978; Minsky, 1975; Kregel, 1980, Carvalho, 1992).

What is much more difficult to find is a conscious effort to link short periods, ${ }^{29}$ building, as suggested by Kalecki (1968), "the long run trend [as] a slowly changing component of a chain of short run situations." That is not by chance. Too strong an emphasis on the potential instability of long run expectations (and hence of investment decisions) inevitably inhibits the modeling of the latter, making Kalecki's suggestion ${ }^{30}$ virtually impossible to follow.

The result is paradoxical: the theory that is most open to the intrinsically dynamic nature of capitalism, deliberately puts on a strait jacket that limits itself to the static determination of equilibrium with unemployment; the study on shifting equilibrium (Kregel,1976) remains a virtuality; the economists potentially more capable - because of their attention to history and to the institutions - to peer "over the edge of the short period" (Robinson, 1978: 80), leave to the orthodoxy the theoretical study on the dynamics. The consequences are potentially disastrous: how can one formulate and legitimate normative judgments without an apparatus that allows the setting up of scenarios where their future implications unfold? How can one turn the intuition that the set of possible economical trajectories is constrained by "institutions and interrelations" into something more than a good idea?

We believe that a middle ground between the excessive emphases on the short term (mostly Post Keynesian) and on the long-term (mostly orthodox) is both essential to the consolidation of the Post Keynesian research program and perfectly feasible from a practical point of view. ${ }^{31}$ In our opinion, institutionally rich stock-flow consistent models, originally proposed by Tobin (e.g. 1980 and 1982) in the context of the neoclassical synthesis and later developed by Godley (1996, 1999a), Lavoie and Godley (2001 - 2002) and Godley and Lavoie (2007), inter alia, from a Post Keynesian perspective, are a very

\footnotetext{
${ }^{27}$ Carvalho seems to suggest that formal models, which inevitably require certain simplifications, are necessarily problematic, which seems doubtful to us.

${ }^{28}$ In the text Carvalho refers to all "schools" mentioned as Post Keynesians. Here we use the adjective to the tradition associated with Kalecki's and with the triad mentioned above (having in mind that Davidson himself - cf. 2003 - $2004-$ seems to consider that definition too wide).

${ }^{29}$ A remarkable exception is naturally Minsky's contribution, which is full of insights, but exposed too informally by the author.

${ }^{30}$ Which is very close to Carvalho's (1990: 288-289) view that Post Keynesian analyses of longer runs should be based on the "study of the factors of continuity that connect each short period to the next". Note that Carvalho (1990) differentiates the concepts of long period (which regards the "degree of completeness" of processes in a theoretical study) from long run (which regards the real passage of time, that is, the "calendar time"). In the text mentioned he refers specifically to "long period" analyses. For us, the problem starts at the analyses of any period that is longer than the period of production. That is why we prefer to say "medium period", a terminology that does not have the connotations of adjustment ( e.g. of the capital stock) associated to the expression "long run", even in the Keynesian tradition.

${ }^{31}$ In this sense, we entirely agree with, yes, Solow (2000) about the necessity of developing the macroeconomics of the medium-run.
} 
decent approximation of this middle ground. ${ }^{32}$ In order to develop this last point (in section 5 and 6 below), it is helpful to remind the reader of (i) the importance of the portfolio decisions of wealth-owners for the determination of Keynesian short period equilibrium (in section 3); and (ii) the importance of taking the heterogeneity between economic agents seriously when developing a "political economy" point of view compatible with (and crucial to) Keynesian macrodynamic analyses (section 4).

\section{The dynamics of wealth in Keynes and the poverty of Keynesian dynamics.}

The simplism of conventional interpretations of the General Theory has been systematically criticized by Post Keynesians. Models such as IS-LM or the $45^{\circ}$ straight line, besides several other problems, neglect one of Keynes' most important contributions: chapter 17 of the General Theory. In this chapter, Keynes presents the basic elements of a theory of portfolio decisions (Carvalho, 1997, Kregel, 1983 and 1997 and Possas, 1986 and 1987). This theory - that goes from the essential attributes of assets to a (preliminary) description of the way agents interact when they decide to alter their portfolios - is crucial to the understanding of both the Keynesian short period equilibrium and the theoretical prerequisites for the construction of truly macrodynamic Post Keynesian analyses.

For Keynes, at every moment in time the multiple agents that form the "wealth-owning class" (Keynes, 1936: 93) enjoy the privilege of changing the composition of their stocks of wealth - counting on the existence of more or less liquid and organized markets (Davidson, 1972/1978) and on the capacity of raising funds through credit (Minsky, 1986). ${ }^{33}$ Prices and quantities of both assets and liabilities are determined by this patrimonial game - in which saving flows play only a secondary ("trifling") role (Keynes, 1930; Davidson, 1972/1978). Changes in the liquidity preference of agents, for example, can generate a new vector of asset prices entirely different from the previous one. ${ }^{34}$ And decisions to acquire (new and/or old) financial or productive assets can lead to the emission of new liabilities whenever these are necessary for the financing of expenses. ${ }^{35}$

Among the many prices determined by the interaction of wealth owners, "demand prices" of productive assets are especially important. Indeed, investment decisions - and, therefore, the levels of production, employment, and the well-being of the whole community - are determined precisely by the differences between the demand prices and current production prices (which, for Keynes, are anchored in the level of nominal wages and state of the art of the technology).

In other words, the causal chain, as interpreted by many Post Keynesians, starts in chapter 17 and then goes all the way back to chapter $3 .^{36}$ In this interpretation, macroeconomic investigation must reflect the existence of a hierarchy that comes from wealth in general - multifaceted and mobile - to productive wealth. The decisions to produce and to employ are only sub-products of a wider search by wealth-

\footnotetext{
32 Of course, the concern with the consistency between stocks and flows did not come up neither with Tobin nor with Godley and Cripps (1983). Restricting ourselves to heterodox authors, there are important contributions by Lerner, Steindl, Davidson and Minsky and many others. However, it is Tobin who first presents a relatively complete and sequential model of an economy with well-developed financial markets. For a colorful depiction of the processes such models try to bring forward, see the first pages of Backus et alii (1980).

${ }^{33}$ The importance of credit is emphasized neither in chapter 17 nor in the rest of the General Theory (see Macedo and Silva, 2007). However, there is not doubt that there are several passages in which Keynes shows he is perfectly aware of the importance of credit for the financing of both strictly financial operations (such as the acquisition and carrying of stocks) and current production and investment. The theme also appears many times in the Treatise and in the famous series of articles published after the General Theory.

${ }^{34}$ This is the reason for Kregel's (and before him, Towshend's) insistence that the chapter 17 must be understood as part of a theory of value. See Towshend (1937) and Kregel (1997 and 1998).

${ }^{35}$ So, as Keynes points out, (1937b, for example) the decision to invest requires the mobilization of finance (by means of bank loans, for example) as well as the subsequent emission of adequate liabilities to the operation funding (Davidson, 1965 and Carvalho, 1996, among others).

${ }^{36}$ This, of course, coincides with both Minsky's interpretation (see for instance 1975: 132) and with Kregel's exegetical effort that culminates in his 1997 "second edition" version for chapter 17 (see also Kregel, 1983, 1988, and for a textbook version, Macedo e Silva, 1999).
} 
owners and capitalist) for ways increase their wealth. The last link of the causal chain consists of the determination of aggregate income and employment, ${ }^{37}$ as well as of the actual level of real wages. ${ }^{38}$

Of course, one can question the way Keynes discards, with no greater justification, a more careful analysis of possible ex antelex post intra-period dynamics (Macedo e Silva, 1995). However, it is not improper to argue (following Kregel, 1976) that the core determinants of aggregate employment in Keynes' theory are the portfolio decisions of wealth-owners (and not the accuracy or inaccuracy of capitalists' short period expectations about the point of effective demand).

That being said, it is necessary to recognize that a theory of aggregate employment in any short period is only the starting point for a much more important and complex issue: how do capitalist economies behave over bigger chunks of historical time? And here Joan Robinson's statement that "Keynes hardly ever peered over the edge of the short period" (Robinson, 1978, p.80) is rigorously correct.

It is clear that in the General Theory there is a huge collection of insights related (in a way) to the dynamics of economies over longer periods. In chapter 17 (or 24) Keynes dares to cast a look at the long run trends of the capitalist economy. ${ }^{39}$ In chapter 19 he organizes in a brilliant way the conditioning factors of several possible courses of an economy in deflation. And in chapter 22, of course, he deals with the economic cycle. However, Keynes' goal in this chapter is clearly modest: he wants to connect previous contributions (including his own in the Treatise) to the new theory, with a strong emphasis on the "crisis" phenomenon. In particular, Keynes makes no attempt to "link short periods". And, yet, nothing would be more natural than building a narrative of the course of an economy taking the short period (whose nature he had just made clear) as the time unit. ${ }^{40}$

With the purpose of building and defending a conceptual fortress centered in the idea of equilibrium with unemployment, Keynes was able to identify and mobilize several of the necessary elements for a more complete dynamic theory. However, his contribution was only partially used by economists, who, after the General Theory, tried to elaborate dynamic theories based on the principle of effective demand, particularly ones based on the interaction between the multiplier and the accelerator effects. Essentially, these theories describe the movement by which investment, as it changes the capital stock and the income level, determines a new capital/product ratio, which, in turn, affects investment in the next period. These theories are undoubtedly dynamic. However, in light of the General Theory, one can question the merits of an investment theory without visible articulations with a more general theory of wealth. Models such as Harrod's (1939) or Kalecki's (1954) subscribe, to a large extent, the simplistic interpretations of the General Theory that were criticized by Post Keynesians. Despite contributing with important insights about the dynamics of effective demand, these models make tabula rasa of the financial aspects, whose centrality Keynes underlined both in Treatise and in the General Theory.

Post Keynesians - following the writings of authors like Davidson and Minsky - have made a big effort to restore the cast of economic actors and institutions emphasized by Keynes. They called back to the stage commercial and investment banks, the stock market and non-financial agents (the so-called "savers", as Keynes used to call them) that operate portfolios in which there are stocks and other debt

\footnotetext{
${ }^{37}$ To be more precise, the "process" starts with the portfolio decisions and finishes with the end of the multiplier effect. The "intra-period" dynamics is simplified through the hypothesis (implicit in the General Theory and only revealed in the class notes of 1937) that short run expectations are always correct, or if not, that expectation errors are just "inconsequent slips", which do not alter the point of effective demand and are quickly eliminated. See Keynes, 1937c.

38 In Carvalho's words (1992: 45), Keynes' approach obeys the "principle of dominant strategy", which recognizes the different powers of agents to determine macroeconomic outcomes - and subverts the neoclassical view in which the workers are co-responsible with the companies for the determination of the employment level .

${ }^{39}$ For example, when he foresees the difficulties deriving from the inflexibility of the interest rates and of the growing abundance of capital.

${ }^{40}$ According to Harcourt (1982: 259), Keynes "had all but despaired of finding a determinate unit of time into which all the various interrelated processes and decisions he was analyzing could be fitted - so he decided not to push any particular piece of analysis very far from its starting point". And, of course, in his 1937 drafts, he actually explains why he gave up the attempt at building a precise relation between ex ante "effective demand" and ex post "income". While agreeing with Kregel (1983: 66) that "the integration of monetary and real analysis [is] the crucial factor in Keynes's discussion" (and not expectations and their fulfillment or not), we do think that the short period is an appropriate unit of time (though it requires a certain number of non-trivial simplifying assumptions; see for instance Possas, 1987, Amadeo, 1989, and Asimakopulos, 1991).
} 
instruments. But, at best, Davidson and Minsky outlined partial scenarios or trajectories in which some agents' interactions are followed (as for example, in the typical description by Minsky of the progressive weakening of firms' and banks' portfolios during optimistic times). It is telling, in our opinion, that the final chapters of Money and Real World - a book of many and undeniable merits - restrict themselves to describing, in excruciating detail, the (many and complex) financial interactions implicit in the determination of the short period equilibrium.

In our opinion, SFC models simultaneously formalize and make explicitly dynamic the "historical model(s)" presented by Davidson in the final chapters of Money and the Real World. In this sense, SFC models are theoretically very close to formal Minskyan models (e.g. Taylor and O'Connell, 1985; Skott, 1994; Taylor, 1991, chapter 5) - which also incorporate many of the "financial" elements emphasized in the General Theory (and in the Treatise) in an explicitly dynamic context. Our problem with this literature is that it does not try, in general, to model balance sheet dynamics rigorously - so as to make the dynamic trajectories generated by these models either theoretically incomplete ${ }^{41}$ (in the best hypotheses) or logically absurd (in the worst. See Dos Santos, 2005).

\section{4 - The social structure in Keynes and in SFC models}

Keynes inherited from the classical tradition the idea that in order to understand how capitalist economies work it is necessary to take explicitly into consideration the different roles played by the main social categories/institutional sectors in these economies. This is crystal clear already in the Tract, where he splits society into three "classes", i.e. (i) the investing class, which consists of the owners of financial assets (or the rentiers of the General Theory); (ii) the business class (or "active class")",;2 and (iii) the working class. Despite recognizing the existence of individual overlaps, Keynes argues that this division illuminates a "social cleavage and an actual divergence of interest" (Keynes, 1923: 4). ${ }^{43}$ In the Tract, maybe more than in any other of his books, this cleavage is integrated into the study of economic themes such as growth, inflation and deflation, income and wealth distribution. Let us, then, have a quick look at some of Keynes's insights in the Tract.

The entrepreneur is the "prop of society" and "the builder of the future" (p 24) because he is solely responsible for increases in the economy's productive capacity. In order to accomplish that, he needs to establish financing contracts with the members of the investing class. But the harmony between the interests of these two classes is precarious at best. In fact, the historical process may result in situations in which the "dead hand" (p. 9) of the stock of private and public debt becomes an obstacle to growth and to the very preservation of the social order. ${ }^{44}$ The typical case considered by Keynes is the one in which deflation fosters a redistribution of income and wealth in favor of the rentiers, hurting workers, entrepreneurs and the public finances. Production shrinks in this scenario because both the fall in prices and the real increase in debt reduce the real profit expected by the entrepreneurs.

This argument would be further developed in chapter 19 of the General Theory. Incidentally, it is interesting to note how the mere consideration of a more complex social structure already casts doubt on the existence of an inverse relation between prices and levels of production (that later would become part of the neoclassical synthesis conventional wisdom, in the form of the so-called aggregate demand schedule).

\footnotetext{
${ }^{41}$ For they focus only on one or another institutional sector, neglecting the inter-relations of such sectors with the others (i.e. those which are only implicit in the models).

${ }^{42}$ It is interesting to note Keynes' concern (1923) about the historicity of this classification. He points out that during the $19^{\text {th }}$ century the separation between property and management divided the "propertied class" (p.5) into investors and entrepreneurs - and allowed fast and balanced growth of both "capital and population" (p.29). As it is well known, this theme would be brought up again, though in a distinctive theoretical context, in chapter 12 of the General Theory.

${ }^{43}$ In the Tract, Keynes also mentions the State and its own interests as well as those of the "middle class" (whose savings would be the "creation and pride of $19^{\text {th }}$ century", p. 12) and of different components of the active class (such as farmers and industry owners).

${ }^{44}$ Of course, the opposition between the rentiers" "old" wealth and "new" wealth, which can only be created by businessmen, would also reappear in General Theory.
} 
What is still more interesting - almost shocking, in fact, in the present political-ideological context - is Keynes's argument that "nothing can preserve the integrity of contract between individuals, except a discretionary authority in the State to revise what has become intolerable" (p. 56). ${ }^{45}$ In other words, the reproduction of a social-economic order based on the establishment of contracts may require regimechanging State interventions from time to time. ${ }^{46}$

Be that as it may, for the purposes of this text we want to call attention to the affinity between the characteristics of the SFC approach and Keynes' emphasis on the importance of taking explicitly into consideration the different interests of the various economic agents (and the interdependencies between them). In particular, in SFC models:

a. Economic agents are, in a large measure, defined by the nature of the stocks of wealth (type, liquidity, international mobility...) carried by them and by their net worth.

b. The different agents celebrate contracts that change their balance sheets and generate money flows that end up determining new changes in their balance sheets.

c. There are extensive chains of inter-relations between agents' assets and liabilities, ${ }^{47}$ making explicit the fact that they have different (and often contradictory) interests.

d. Variations in the value of stocks that come from capital gains or losses have decisive implications for the agents' future decisions and, therefore, for the dynamics of the system.

e. As the economy grows, agents tend to accumulate a growing volume of assets and liabilities. Trajectories in which portfolios grow in a balanced way are theoretically possible. But in practice the accumulation of assets and liabilities is far from balanced. Agents' and sectors' portfolios tend to evolve in asymmetric ways, with varying degrees of leverage, risk and liquidity.

f. Courses in which the balance sheets of large parts or even whole institutional sectors (as productive companies or households) become more fragile can lead to regime changing structural breaks due to endogenous reasons and/or to exogenous shocks.

g. The accumulation of assets and liabilities also promotes the creation and distribution of political power (a concept that is almost a taboo among mainstream economists). In other words, keeping track of the medium term sectoral stock-flow dynamics sheds considerable light not only on the likelihood of future financial crises, but also on the possible (economic and political economy) consequences of the latter. One has a much better chance of understanding how a crisis situation will evolve to a new post-crisis regime if one knows which interests generated (and were hurt by) the crisis in the first place.

We believe that most Post Keynesians would agree that the characteristics above are theoretically compatible with the Post Keynesian "vision" on the (inter-related) economic and political dynamics of capitalist economists in historical time. It is, then, time for us to present the reasons why we believe these characteristics are present in SFC models.

\section{Stock-Flow Consistent Models: What are they and why is that so}

There are several ways to define SFC models. ${ }^{48}$ It seems to us, however, that the best way to understand what exactly is an SFC model is to follow the necessary steps to the construction of one of these models.

The first thing one needs to do in order to build an SFC model is to define the relevant economic agents (or social categories/ institutional sectors) and all their respective (and interdependent) assets and liabilities. Which agents, assets and liabilities one chooses depend crucially on the context one wants to analyze. State-owned enterprises, for instance, played a crucial role in the dynamics of the Brazilian

\footnotetext{
${ }^{45}$ This is the famous passage in which Keynes states that the "absolutists of contract (...) are the real parents of revolution".

46 "Everything must change so that everything can stay the same", in Lampedusa's words...

${ }^{47}$ A bank loan is simultaneously a liability to firms and an asset to banks. Firms's capital is partially owned by households, which also own bank deposits. These, in turn, are liabilities to banks, and so on.

${ }^{48}$ In the introduction to this text we defined them as "models in which economic agents are identified with the main social categories/institutional sectors, the short period behavior of these agents is thoroughly described, and the "period by period" balance sheet dynamics implied by the latter is consistently modeled". Dos Santos (2006: 543-544), in turn, prefers models "in which the balance sheet dynamics of all assumed institutional sectors (given by sectoral saving flows, portfolio shifts, and capital gains) are explicitly and rigorously modeled".
} 
economy in the 1970's - according, for example, to Davidoff Cruz (1984) and Werneck (1987) - so it is only natural to include those in a SFC description of the Brazilian economy in that period. If, however, one is looking at the American economy of the 1990's - as described, for example, by Godley (1999) or Papadimitriou et al. (2003) - the exclusion of state-owned enterprises is perfectly justifiable. On the other hand, the behavior of stock markets was not particularly important to the dynamics of the Brazilian economy of the 1970s, but was decisive in the U.S in the 1990s, so it seems reasonable to simplify away these markets in a SFC depiction of the Brazilian economy of the 1970s but not in a depiction of the American economy of the 1990s.

Following Dos Santos (2006), we believe it is possible to argue that a large number of Keynesians converged, around the 1970 s, to a model in which the short period equilibrium in a closed capitalist economy depends crucially on the inter-related behavior of households, firms, the government, and the financial sector. The first step for the construction of a SFC version of this "financial-Keynesian" model is to write down the balance sheets of these agents/ institutional sectors, as in the table 1.

\begin{tabular}{|l|l|l|l|l|l|l|}
\hline \multicolumn{7}{|l|}{ Table 1. Nominal balance sheets in our 'artificial Keynesian economy' } \\
\hline & $\begin{array}{l}\text { Household } \\
\mathrm{s}\end{array}$ & Firms & $\begin{array}{l}\text { Bank } \\
\mathrm{s}\end{array}$ & $\begin{array}{l}\text { Central } \\
\text { Bank }\end{array}$ & $\begin{array}{l}\text { Governme } \\
\text { nt }\end{array}$ & $\begin{array}{l}\text { Row } \\
\text { Totals }\end{array}$ \\
\hline $\begin{array}{l}1-\text { High-Powered } \\
\text { Money }\end{array}$ & $+H h$ & & $+H b$ & $-H$ & 0 \\
\hline $\begin{array}{l}2-\text { Central Bank } \\
\text { Advances }\end{array}$ & & & $-A$ & $+A$ & & 0 \\
\hline $3-$ Bank Deposits & $+M h$ & $+M f$ & $-M$ & & & 0 \\
\hline $4-$ Bank Loans & & $-L$ & $+L$ & & & 0 \\
\hline $5-$ Govt. Bills & $+B h$ & & $+B b$ & $+B c$ & $-B$ & 0 \\
\hline $6-$ Capital & & $+p \cdot k$ & & & & $+p \cdot k$ \\
\hline $7-$ Equities & $+p e \cdot E$ & $-p e \cdot E$ & & & & 0 \\
\hline $\begin{array}{l}8-\text { Net Worth (Col. } \\
\text { Totals) }\end{array}$ & $+V h$ & $+V f$ & 0 & 0 & $-B$ & $+p \cdot k$ \\
\hline
\end{tabular}

Note: $\mathrm{p}$ and $\mathrm{k}$ stand, respectively, for the price of the single good produced in the economy and the number of units of this good used in production, while pe and $\mathrm{E}$ stand for the price of one equity and the number of equities issued. A ( + ) before a variable denotes an asset while a (-) denotes a liability.

As mentioned in items (a) and (c) of section 4, table 1 explicitly identifies the economic agents with their (interdependent) assets and liabilities. An example: enterprises are supposed to have capital goods and some money in the bank, financed either with capitalists' own money and/or by bank loans (which appear as assets in the portfolios of financial institutions) or the selling of equities (which appear as assets in the portfolio of households).

At this point the reader could perfectly ask himself why is it that in the economy depicted above households neither get bank loans nor have any real estate or why the government does not hold any cash. The answer is simple: such assets and liabilities do not play an important role in the "stories" told, for instance, by Davidson (in the final chapters of Money and the Real World), Minsky (e.g. 1982, 1986), Tobin (1981) and/or Godley (e.g. 1996) - the "financial-Keynesians" discussed by Dos Santos (2006). But nothing prevents one from adding these variables if one wants (or has) to work with more complex models. Both the growth of households' debt and the real estate appreciation/devaluation cycle were crucial determinants of the dynamics of the American economy after 2001, for example. It therefore seems natural to include them in SFC models of the latter. In any case, it is important to emphasize that as mentioned in item (b) of section 4 - table 1 is only the beginning of our "story" or, more specifically, of the "short period" (which, following Asimakopulos, 1991, we identify with the short run of some months to one year). The stocks of wealth and debt mentioned above - besides, of course, the flow of productive activities characteristic of capitalism - generate several financial flows between sectors, which 
in turn change their balance sheets at the end of each short (and accounting) period. Table 2 depicts these flows and their patrimonial consequences.

Despite its unfriendly appearance, table 2 depicts very intuitive phenomena. As in virtually all capitalist economies, households earn salaries, dividends, interest on their financial assets (i.e. bank deposits and/or government bills) and use part of this money to buy goods and pay taxes, keeping the rest (i.e. their saving flows) to increase their wealth, which is also modified by capital gains/losses. Banks, in turn, make money exploiting the difference between the interests they pay for customers' deposits (and, if they need it, for Central Bank advances) and the interests they receive from loans (to companies and/or the government). In table 2, banks' profits are zero, but this is only because this variable does not play any role in the "stories" told by "financial Keynesians" (Dos Santos, 2006). The hypotheses made about companies and the government are also quite familiar to Post Keynesians.

But even if one does not one agree with us that the "artificial economy" described above is sufficiently representative of the broad Post Keynesian vision around the 1970s, we believe he or she will agree with our more general point, i.e. that the transactions which are implicit in each short period Keynesian equilibrium have important and non-trivial balance sheet implications. In other words, agents' balance sheets at the end of each short period will necessarily be different from what they were in the beginning of the period.

\begin{tabular}{|c|c|c|c|c|c|c|c|c|c|c|c|}
\hline \multicolumn{12}{|c|}{ Table 2. Nominal Transactions in our 'artificial Keynesian economy'. } \\
\hline & \multicolumn{2}{|c|}{$\begin{array}{l}\text { Household } \\
\mathrm{s}\end{array}$} & \multicolumn{2}{|c|}{ Firms } & \multicolumn{2}{|c|}{ Banks } & \multicolumn{2}{|c|}{$\begin{array}{l}\text { Governme } \\
\mathrm{nt}\end{array}$} & \multicolumn{2}{|c|}{ C. Bank } & \\
\hline & $\begin{array}{l}\text { Curren } \\
\mathrm{t}\end{array}$ & Cap. & $\begin{array}{l}\text { Curren } \\
\mathrm{t}\end{array}$ & Cap. & Curr. & Cap & $\begin{array}{l}\text { Curren } \\
\mathrm{t}\end{array}$ & Cap. & Curr. & Cap. & $\begin{array}{l}\text { Row } \\
\text { Total }\end{array}$ \\
\hline 1-Cons. & $-C$ & & $+C+G$ & & & & $-G$ & & & & 0 \\
\hline 2- Invest. & & & $+p \cdot \Delta k$ & $\bar{p} \cdot \Delta k$ & & & & & & & 0 \\
\hline $3-$ Wages & $+\mathrm{W}$ & & $-\mathrm{W}$ & & & & & & & & 0 \\
\hline $4-$ Taxes & $-\mathrm{Th}$ & & $-\mathrm{Tf}$ & & & & $+\mathrm{T}$ & & & & 0 \\
\hline $\begin{array}{l}5- \\
\text { Interest } \\
\text { on Loans }\end{array}$ & & & $\begin{array}{l}-\mathrm{rl}_{-1} \\
\mathrm{~L}_{-1}\end{array}$ & & $\begin{array}{l}+\mathrm{rl}_{-1} \\
\mathrm{~L}_{-1} \\
-\mathrm{ra}_{-1} \\
\mathrm{~A}_{-1}\end{array}$ & & & & $\begin{array}{l}+\mathrm{ra}_{-} \\
1 \cdot \mathrm{A}_{-} \\
1\end{array}$ & & 0 \\
\hline $\begin{array}{l}6- \\
\text { Interest } \\
\text { on Bills }\end{array}$ & $\begin{array}{l}+\mathrm{rb}_{-1} \\
\mathrm{Bh}_{-1}\end{array}$ & & & & $\begin{array}{l}+\mathrm{rb}_{-1} \\
\mathrm{Bb}_{-1}\end{array}$ & & $\begin{array}{l}-\mathrm{rb}_{-1} \\
\mathrm{~B}_{-1}\end{array}$ & & $\begin{array}{l}+\mathrm{rb}_{-} \\
1 \\
\mathrm{Bc}_{-1}\end{array}$ & & 0 \\
\hline $\begin{array}{l}7-\text { Int on } \\
\text { Deposits }\end{array}$ & $\begin{array}{l}+\mathrm{rm}_{-1} \cdot \\
\mathrm{Mh}_{-1}\end{array}$ & & $\begin{array}{l}+\mathrm{rm}_{-1} \\
\mathrm{Mf}_{-1}\end{array}$ & & $\begin{array}{l}-\mathrm{rm}_{-} \\
1 \cdot \mathrm{M}_{-} \\
1\end{array}$ & & & & & & 0 \\
\hline $\begin{array}{l}8- \\
\text { Dividends }\end{array}$ & $\begin{array}{l}+\mathrm{Ff}+\mathrm{F} \\
\mathrm{b}\end{array}$ & & $-\mathrm{Ff}$ & & $-\mathrm{Fb}$ & & $+\mathrm{Fc}$ & & $-\mathrm{Fc}$ & & 0 \\
\hline \multicolumn{12}{|c|}{ Uses and Sources of Funds } \\
\hline $\begin{array}{l}\text { 9- Current } \\
\text { Saving } \\
\text { (col. total) }\end{array}$ & $\begin{array}{l}+\mathrm{SA} \\
\mathrm{Vh}\end{array}$ & & $+\mathrm{Fu}$ & & 0 & & $\begin{array}{l}+\mathrm{SAV} \\
\mathrm{g}\end{array}$ & & 0 & & $+S A V$ \\
\hline $10-\Delta$ Cash & & - & & & & - & & & & $+\Delta H$ & 0 \\
\hline
\end{tabular}




\begin{tabular}{|c|c|c|c|c|c|c|c|c|c|}
\hline $\begin{array}{l}11-\Delta \mathrm{CB} \\
\text { Advances }\end{array}$ & & & & $\begin{array}{l}+\Delta \\
A\end{array}$ & & & & $-\triangle A$ & 0 \\
\hline $\begin{array}{l}\text { 12- } \Delta \text { Bank } \\
\text { Deposits }\end{array}$ & & - & $-\Delta M f$ & $\begin{array}{l}+4 \\
M\end{array}$ & & & & & 0 \\
\hline 13- $\Delta$ Loans & & & $+\Delta L$ & $-\Delta L$ & & & & & 0 \\
\hline $\begin{array}{l}\text { 14- } \Delta \text { Govt. } \\
\text { Bills }\end{array}$ & & $-\overline{\Delta B h}$ & & - & & $+\Delta B$ & & $-\triangle B c$ & 0 \\
\hline $\begin{array}{l}15- \\
\Delta \text { Equities }\end{array}$ & & $\begin{array}{l}-p e \\
\Delta E\end{array}$ & $\begin{array}{l}+p e \\
\Delta E\end{array}$ & & & & & & 0 \\
\hline $\begin{array}{l}16- \\
\text { Curr.Sav. } \\
+ \text { Net } \\
\text { Capital } \\
\text { Transaction } \\
\text { s }\end{array}$ & 0 & & 0 & 0 & 0 & & 0 & & 0 \\
\hline \multicolumn{10}{|c|}{ Accounting Memos } \\
\hline $\begin{array}{l}17-\Delta \mathrm{Net} \\
\text { Worth }\end{array}$ & $\begin{array}{l}S A V h+ \\
\Delta p e \cdot E_{-1}\end{array}$ & & $\begin{array}{l}F u+\Delta p \cdot k_{-1}- \\
\Delta p e \cdot E_{-1}\end{array}$ & 0 & $S A V g$ & & 0 & & $\begin{array}{l}S A V+ \\
\Delta p \cdot k_{-1}\end{array}$ \\
\hline \multicolumn{10}{|c|}{18 - Final Sales $\equiv S \equiv C+G+p \cdot \Delta k \equiv W+F T \equiv Y$} \\
\hline \multicolumn{10}{|c|}{19 - Firms' Gross Profits $\equiv F T \equiv S-W$} \\
\hline \multicolumn{10}{|c|}{20 - Households' Disposable Income $\equiv Y h \equiv W+r b_{-1} \cdot B h_{-1}+r m_{-1} \cdot M h_{-1}+F f+F b-T h$} \\
\hline \multicolumn{10}{|c|}{21 - Government's Disposable Income $\equiv \mathrm{Yg} \equiv \mathrm{T}-\mathrm{rb}_{-1} \cdot \mathrm{B}_{-1}+\mathrm{Fc}$} \\
\hline
\end{tabular}

Note: $A(+)$ sign before a variable denotes a receipt (or source of funds) while a (-) sign denotes a payment (or use of funds).

Of course, accounting frameworks should not be confounded with theoretical models. The latter must necessarily include behavioral hypotheses about the variables that appear in the accounting. ${ }^{49}$ But, if we think - following chapter 17 in the General Theory - that the portfolio choices of the agents are crucial determinants of the equilibrium in each short period, then the linking of short periods presupposes that the balance sheet implications of each one of these periods are rigorously mapped (given that they will affect the agents' portfolio decisions in the following period.) That is the very "raison d' être" of the (only apparently) complicated accounting frameworks that characterize SFC models.

\section{Keynes' long period equilibrium and the Post Keynesian medium-run}

To be sure, the tracking of the balance sheet implications of any short period (dis)equilibrium is not enough to link it with the following period. In order to do so, one needs also to state how the behavior of agents in period $t+1$ will be affected by the (dis)equilibrium in period $t$-i.e. one needs also to specify whether and how the parameters of the behavioral functions vary from period to period. For example, an exceptional growth in production in short period $t$ could bring a change in the state of long run expectations and/or in the liquidity preference of businessmen in period $t+1$. And the same reasoning applies, of course, to all the many behavioral hypotheses (about the various agents) one needs to make in order to "close" any model of, for instance, the artificial economy described above.

Draconian demands regarding the completeness of the modeling of the "reaction functions" 50 of the various economic agents that are typically considered in financial Post Keynesian parables ${ }^{51}$

\footnotetext{
49 Dos Santos (2006) presents a detailed description of the behavioral hypotheses assumed by Minsky, Davidson, Tobin and Godley in several contexts.

50 Perhaps the origins of such draconian demands are to be found in the ambition to create a theory in historical time and/or in the frustration with the fact that Keynesianism came to be identified with the neoclassical synthesis. In the latter (as in most
} 
represent, in our opinion, the main obstacle to the construction of Post Keynesian "stories" which go beyond the short period. It seems to us, however, that this need is only apparent. In order to explain our reasons, it is convenient to revisit the concept of long period equilibrium and the notion of stability presented in the General Theory.

In chapter 5 of the General Theory, chapter 5, Keynes makes a considerable effort to introduce one of the least seminal ideas of the book:

"If we suppose a state of expectation to continue for a sufficient length of time for the effect on employment to have worked itself out so completely that there is, broadly speaking, no piece of employment going on, which would not have taken place if the new state of expectation had always existed, the steady level of employment thus attained may be called the long period employment corresponding to that state of expectation" (Keynes, 1936: 48).

In a first reading, the concept of long period employment seems irremediably static and (therefore) irrelevant. It is static because it is built on the hypothesis of a given state of expectations. It is irrelevant because the very essence of Keynes' message in the General Theory - which was made even clearer in the famous article of 1937 - is the importance of the instability of expectations to the determination of the level of activity. What good does it do, in this context, to know that:

"although expectation may change so frequently that the actual level of employment has never had time to reach the long period employment corresponding to the existing state of expectation, nevertheless every state of expectation has its definite corresponding level of long period employment" (id. ibid.)?

It is true that the concept of long period equilibrium is consistent with some dynamics: in the footnote, Keynes explains that the hypothesis of a certain state of expectations is compatible with steady growth of income and population and, consequently of employment (Asimakopulos, 1984-85). However, one must recognize that: (i) this type of approach has never pleased Keynes' most direct heirs, with the possible exception of Joan Robinson's brief flirt; ${ }^{52}$ and (ii) the concept of long period equilibrium in Keynes suffers from the same institutional "poverty" we identified in the Post Keynesian attempts to go beyond the short period in section 3 .

In our opinion, SFC models allow a wider, more precise and explicitly dynamic approach to a Keynesian modeling of the passage of time. In fact, we believe that the analysis of sequences of short period (and, therefore, long period ${ }^{53}$ ) equilibria can be useful both for ex post historical analyses and for the making of future scenarios.

Note that the short and long period equilibria in the General Theory bring to the fore solely the expectations related to the universe of production: the state of long period expectations is given; short period expectations are fulfilled. The oft-quoted taxonomy of models identified by Kregel (1976) shares the same "minimalist" approach: it is built as a simple matrix where the only things that matter are whether short period expectations are fulfilled and whether their falsification influences capitalists' decisions to invest. However, taking into account a more complete set of agents with fully specified portfolios allows for a wider array of expectations and a wider definition of equilibrium.

neoclassical elaborations), the "freezing" of parameters really aims at assuring, aprioristically, the convergence to general equilibrium. The arbitrariness of such procedures, from the scientific standpoint, is efficiently denounced in chapter 19 of the General Theory. In this masterful text, Keynes elicits almost every possible change in the independent variables of his "model", and envisages possible trajectories in the context of a more complex social structure and of an open economy. This is certainly an excellent way to start, but it should not be considered the end of dynamic economics. The temporary "freezing" of parameters does not in itself mean a conciliation with the idea of convergence to a pre-determined (even less than optimum) long run configuration - besides being consistent (see below) with Keynes's own perception that capitalism often presents periods of relative stability.

51 Again, the last chapters of Money and the Real World come up to our minds.

52 One should not forget that the concept was also reclaimed by neoricardians such as Eatwell and Milgate, but in the context of their attempt - very different from ours - at building a long period version of the principle of effective demand

${ }^{53}$ For, as Keynes notes in the passage above, each short period equilibrium (implied, among other things, by a given state of long term expectations) has a corresponding long period one (associated with the same state of long term expectations). 
Note also that in the construction of an SFC model, it is perfectly possible to introduce any kind and degree of disequilibrium. ${ }^{54}$ One can, for instance, suppose that agents' expectations about both their income and asset prices are always wrong. One can also suppose that agents strongly react to these disequilibria, making them cumulative and explosive. However, it so happens that this description of capitalist economies - as a system in "permanent crisis" (which, according to Marx, is impossible) or even as a system always on the verge of rupture - does not seem to agree with Keynes" own views on the issue $^{55}$ (besides being problematic from an empirical point of view). In chapter 18 of the General Theory, after describing the determination of employment and income in a way that is (dangerously) close to the IS-LM model, Keynes states that:

"In particular, it is an outstanding characteristic of the economic system in which we live that, whilst it is subject to severe fluctuations in respect of output and employment, it is not violently unstable. Indeed it seems capable of remaining in a chronic condition of subnormal activity for a considerable period without any marked tendency either towards recovery or towards complete collapse" (Keynes, 1936: 249).

Therefore, it seems sensible to use simplifying hypotheses concerning agents' reactions to various kinds of disequilibria when modeling relatively "chronic" (as opposed to "critic") conditions. Moreover, in due accordance with "Professor Robinson's often repeated caveat that the analysis of steady growth has to be fully worked out and understood before moves can be made to the analysis of dynamic change over time" (Kregel, 1976: 220), SFC practitioners normally start from the study of steady-growth states. In fact, SFC models often suppose that (i) in each short period a "Keynesian" equilibrium is reached; ${ }^{56,57}$ and (ii) all (or the great majority of) behavioral parameters remain constant (short) period after (short) period. Having assumed that that short period expectations are correct and that the state of long run expectations (that usually takes the form of a constant parameter in the "investment function" of SFC models) is given (as well as all other parameters), ${ }^{58}$ we believe it is possible to interpret the steady-states resulting from these simulations as sophisticated and useful versions of the long period equilibrium defined in chapter 5 of the General Theory. The sophistication is due to the fact that these steady-states take into consideration the expectations of all economic agents about all flows, stocks and prices of a capitalist economy with complex financial markets (as opposed to only firms' sales expectations).

But why would it be useful to know "where the economy is going" under the obviously unrealistic hypothesis that all the parameters will remain constant? There are at least three good reasons, in our opinion. In order to understand them it is important to have in mind that it is possible to get three kinds of trajectories with SFC models:

- trajectories toward a sustainable steady state;

- trajectories toward a steady state over certain limits;

- explosive trajectories.

The analysis of SFC steady states is useful, firstly, because it makes clear to the analyst whether the regime described in the model is sustainable or whether it leads to some kind of rupture - either because the trajectory is explosive or because it leads to politically unacceptable configurations. In these cases, as Keynes would say in the Tract, the analyst can conclude that something will have to change ${ }^{59}$ and even get clues about (i) what will probably change (since the sensitivity of the system dynamics to

\footnotetext{
${ }^{54}$ After all SFC models are artificial economies, whose courses can always be simulated on the computer.

${ }^{55}$ In spite of the statement that "at all times the vague panic fears and equally vague and unreasoned hopes are not really lulled, and lie but a little way below the surface" (Keynes, 1937:115).

${ }^{56}$ Keeping in mind that the concept here goes beyond the satisfaction of entrepreneurs' short run sales expectations, because it takes into consideration the expectations of all agents about all flows, stocks and asset prices of the economy.

57 This hypothesis is merely a simplifying one - for it saves one the trouble of having to model firms' inventories and the reaction functions of all the agents assumed in the model. But see Godley and Lavoie (2007) for many examples of more complex SFC models.

${ }^{58}$ Of course, nothing (besides the increasing complexity of the models and the existence of huge gaps in the theory and in the empirical knowledge about agents' reactions to disequilibria) prevents bold users from giving up these simplifying hypotheses. The model presented in chapter 12 of Godley and Lavoie (2007) seems to us a perfect example of these more ambitious and "realistic" (and therefore quite complex) SFC models.

${ }^{59}$ Perhaps, but not necessarily, so that everything can stay the same...
} 
changes in different behavioral parameters is not the same); and (ii) when this change will occur (since the system may converge or diverge more or less rapidly).

Secondly, SFC models may help the analyst to identify the requirements for a "socially desirable" steady-growth states and, therefore, to shed light on the normative discussion and on the elaboration of economic policy proposals and scenarios.

Thirdly, they can help historical analysis, since it is relatively easy to "calibrate" them in order to reproduce concrete trajectories whenever the behavioral parameters have remained more or less stable for sufficiently long periods or whenever they move(d) toward a known direction. ${ }^{60}$

All these characteristics are, of course, present in the series of "strategic analyses" on the U.S economy written by Wynne Godley and associates both at the Levy Economics Institute of Bard College and at the University of Cambridge since the end of the 1990s (e.g Godley and McCarthy, 1997, Godley, 1999b; Godley and Izurieta, 2001; Papadimitriou et al. 2004, Godley et al. 2005) ${ }^{61}$. As it is now well known, these papers correctly predicted that the U.S fiscal surpluses of the 1990s would have to be reversed in order to prevent a deep recession (as it eventually happened in 2001) and that this by itself would not be enough to prevent another slowdown of the U.S economy a couple of years ahead (as it eventually happened in 2008), given that household consumption and debt growth levels were not sustainable ${ }^{62}$.

For the purposes of this paper it is important to note that such analyses were not based, of course, on the idea that the parameters of the American economy remained constant during the long boom of the 1990 s or in the 2002-2007 years. Even though there were probably slight variations in, say, American households' propensity to consume during this period, these were far from being particularly large (and therefore important). Quite on the contrary, the analyses were based on the idea that the parameters of the American economy could not remain (approximately) constant indefinitely, for that would imply that certain key stock-flow ratios would increase (or decrease) indefinitely, and that was not deemed plausible in that particular historical context.

In our opinion, the lesson to be learnt from Godley's analysis is that in many historical contexts the tracking of the sectoral balance sheet dynamics under the (often not quite) heroic hypothesis of constant behavioral parameters allows one to get powerful insights about what is "very likely" to happen in the near future (we can never neglect, after all, the hypothesis of exogenous and regime changing structural breaks). And that is precisely the reason why we believe SFC models can be quite useful.

\section{Conclusion}

We believe SFC models are useful tools to economists (especially Post Keynesians) who are not convinced by neoclassical (or classical) parables about the long run and, at the same time, do not accept to limit themselves to short period analyses. Of course, peering over the edge of the short period is difficult and requires another kind of compromise. The economist must always keep in mind that the future is uncertain in the Knight-Keynes sense of the term and that, in these conditions, modesty seems to be a sensible attitude. Given the obviously unrealistic simplifying hypotheses that are assumed in SFC models, the latter are admittedly modest attempts to shed light on aspects of dynamic trajectories of capitalist economies in historical time. ${ }^{63}$

\footnotetext{
${ }^{60}$ As it would be the case, for example, of an exchange crisis caused by the decision of domestic wealth owners to increase their assets denominated in foreign currency.

${ }^{61}$ Another remarkable example is the description by the so-called "Escola de Campinas" (Campinas School) of the patrimonial origins of Brazil's decline to stagnation in the 1980s. In seminal texts, Davidoff Cruz (1984) and Belluzo \& Gomes de Almeida (2002) show: (i) the increasing financial fragility of the Brazilian private sector - and of the Brazilian economy as a whole - in the 1970s caused by the accumulation of foreign liabilities denominated in dollars and with floating interest rates; (ii) the forcing of state-owned enterprises to get foreign, dollar denominated, loans in order to finance the deficit in the current account of the Brazilian balance of payments; (iii) the later "nationalization" of private debt; and (iv) the adjustment process of private companies, accumulating financial surpluses which were the counterparts of increasing public deficits.

${ }_{62}$ Both predictions were quite controversial when they were made.

${ }^{63}$ We repeat that the use of these simplifying hypotheses - many of which involving equilibrium states - does not imply that SFC theorists believe in the existence of long run "centres of gravitation". As Godley and Cripps point out (1983, p.44,
} 
But modest tools are certainly much better than no tools at all, and hence our enthusiasm with the potential of the SFC line of research. ${ }^{64}$ It should not be difficult, in particular, to convince the reader that the Post Keynesian research program will have a much better chance of turning into a real alternative to the dominant paradigm if it encourages its practitioners to go beyond short run analyses. And that is precisely what the SFC approach attempts to do.

\section{REFERENCES}

ACEMOGLU, D. e ROBINSON, J.A. (2007). Economic Origins of Dictatoship and Democracy. Cambridge: Cambridge University Press.

AGHION, P. e BANERJEE, A. (2006). Volatility and Growth. Oxford: Oxford University Press.

AMADEO, E. J. (1989). Keynes's Principle of Effective Demand. Aldershot: Elgar.

ASIMAKOPULOS, A. (1984-5). "Long period employment" in The General Theory. Journal of Post Keynesian Economics, VII (2), 207-213.

ASIMAKOPULOS, A. (1991). Keynes's General Theory of Accumulation. Cambridge: Cambridge.

BACKUS, D., BRAINARD, W. SMITH, G. and TOBIN, J. (1980). A Model of the U.S. Financial and Non-financial Economic Behavior. Journal of Money, Credit and Banking. May, 259-293.

BELLUZZO, L. G. \& GOMES DE ALMEIDA, J. (2002). Depois da queda - a economia brasileira da crise da dívida aos impasses do Real. Rio de Janeiro: Civilização Brasileira.

BLANCHARD, O. (1997/2007). Macroeconomia. São Paulo: Pearson.

BLANCHARD, O e SUMMERS, L (1988). Beyond the Natural Rate Hypothesis. American Economic Review 78, May: 182-187.

CARVALHO, F. C. (1984-5). Alternative analyses of short and long run in Post Keynesian economics. Journal of Post Keynesian Economics, VII (2), 214-234.

CARVALHO, F. C. (1990). Keynes and the long period. Cambridge Journal of Economics, 14, 277-90.

CARVALHO, F. C. (1992). Mr. Keynes and the Post Keynesians - Principles of Macroeconomics for a Monetary Production Economy. Aldershot: Elgar.

CARVALHO, F. C. (1996). Sorting out the issues: the two debates on Keynes' finance motive revisited. Revista Brasileira de Economia, July/Sept, 50 (3), 312-327.

DAVIDOFF, P. C. (1984). Dívida externa e política econômica: a experiência brasileira nos anos 70. Campinas: Unicamp, 1999.

DAVIDSON, P. (1965). Keynes's Finance Motive. Oxford Economic Papers, 17 (1), March, 47-65.

DAVIDSON, P. (1972/1978). Money and the Real World. 2aed., London: Macmillan, 1978.

DAVIDSON, P. (1982-83). Rational expectations: a fallacious foundation for studying crucial decisionmaking processes. Journal of Post Keynesian Economics, v. 5, p. 182-196.

DAVIDSON, P. (2003-04): Setting the Record Straight on. A History of Post Keynesian Economics. Journal of Post Keynesian Economics, 26 (2), 245-272.

DOS SANTOS, C. H. (2004). Notas sobre a crescente (e peculiar) fragilidade financeira do capitalismo norte-americano. Economia e Sociedade, v. 13, n. 2 (23), p. 23-49, jul./dez. 2004.

DOS SANTOS, C. H. (2005) A stock-flow consistent general framework for formal Minskyan analyses of closed economies. Journal of Post-Keynesian Economics, vol. 27, no. 4, 11-35.

DOS SANTOS, C. H. (2006). Keynesian theorising during hard times: stock-flow consistent models as an unexplored 'frontier' of Keynesian macroeconomics. Cambridge Journal of Economics, 30 (4), 541-565.

emphasis on the original), "We do not ask the reader to believe the way economies work can be discovered by deductive reasoning. We take the contrary view. The evolution of whole economies, like their political systems, is a highly contingent historical process. We do not believe that it is possible to establish precise behavioral relationships comparable with the natural laws of physical sciences by techniques of statistical inference. Few laws of economics will hold good across decades or between countries. On the other hand, we must exploit logic so far as we possibly can. Every purchase implies a sale, every money flow comes from somewhere and goes somewhere; only certain configurations of transactions are mutually compatible. The aim here is to show how logic can help to organize information in a way that enables us to learn as much from it as possible. This is what we mean by macroeconomic theory (...)".

${ }^{64}$ See Dos Santos and Zezza (2007) for a review of SFC literature published in recent years. 
DOS SANTOS, C. H. e ZEZZA, G. (2007). A Simplified "Benchmark" Stock-flow Consistent (SFC) Post-Keynesian Growth Model. Working Paper 503, Levy Economics Institute of Bard College, Annandale-on-Hudson, N.Y. Metroeconomica, forthcoming.

GODLEY, W. (1996). Money, Income and Distribution: an Integrated Approach, Working Paper 167, Levy Economics Institute of Bard College, Annandale-on-Hudson, N.Y.

GODLEY, W. (1999a). Money and credit in a Keynesian model of income determination, Cambridge Journal of Economics, vol. 23, no. 4, 393-411

GODLEY, W. (1999b). Seven Unsustainable Processes, Special Report, Levy Economics Institute of Bard College, Annandale-on-Hudson, N.Y.

GODLEY, W. \& CRIPPS, F. (1983). Macroeconomics. Oxford: Oxford University Press.

GODLEY, W. \& McCARTHY, G. (1997) Fiscal Policy Will Matter. Challenge. Vol. 41, No.1, 38-54.

GODLEY, W. \& IZURIETA, A. (2001). As The Implosion Begins . . .? Prospects and Policies for the U.S. Economy: A Strategic View. Levy Economics Institute Strategic Analysis. Annandale-onHudson, NY

GODLEY, W; PAPADIMITRIOU, D; DOS SANTOS, C. \& ZEZZA, G. (2005). The United States and her Creditors; Can the Symbiosis Last? Levy Economics Institute Strategic Analysis. Annandaleon-Hudson, NY

GODLEY, W. \& LAVOIE, M. (2007). Monetary Economics: An Integrated Approach to Credit, Money, Income, Production and Wealth. Nova Iorque: Palgrave MacMillan.

HARCOURT, G. C. (1982). Marshall, Sraffa and Keynes: Incompatible bedfellows?. In Sardoni, C. (ed.). On political economists and modern political economy - selected essays of G. C. Harcourt. New York, London: Routledge, 1992.

HARCOURT, G. C. (1986). Nicholas Kaldor, 1908-1986. In Sardoni (1992).

HARCOURT, G. C. (2006). The structure of Post-Keynesian economics - the core contributions of the pioneers. Cambridge: Cambridge.

HARCOURT, G. C. \& HAMOUDA, O. F. (1988). Post-Keynesianism: from criticism to coherence? In Sardoni (1992).

HARCOURT, G. C. \& SARDONI, C. (1995). George Shackle and Post-Keynesianism. In Capitalism, socialism and Post-Keynesianism - Selected essays of G. C. Harcourt. Aldershot, Brookfield: Elgar.

HARROD, R. (1939). An Essay in Dynamic Theory. Economic Journal, 14-33.

INGRAO, B. \& ISRAEL, G. (1990). The Invisible Hand - Economic Equilibrium in the History of Science. Cambridge: The MIT Press.

KALECKI, M. (1954). Theory of Economic Dynamics - an essay on cyclical and long run changes in capitalist economy. London: Allen \& Unwin. Edição brasileira Abril Cultural, Os Economistas, São Paulo, 1983.

KALECKI, M. (1968). Tendência e ciclo econômico. In Kalecki, M. Crescimento e ciclo das economias capitalistas. São Paulo: Hucitec.

KEYNES, J. M. (1923). A Tract on Monetary Reform. The Collected Writings of John Maynard Keynes (CW), IV. London: Macmillan, 1973.

KEYNES, J. M. (1930). A Treatise on Money. CW vols. V e VI.

KEYNES, J. M. (1934). Poverty in plenty: is the economic system self-adjusting? CW XIII.

KEYNES, J. M. (1936). The General Theory of Employment, Interest and Money. CW VII.

KEYNES, J. M. (1937a). The general theory of employment, 1937b. Reprinted in CW XIV.

KEYNES, J. M. (1937b) Alternative Theories of the Rate of Interest. Reprinted in CW XIV.

KEYNES, J. M. (1937c). Ex Post and Ex Ante. CW, vol. XIV.

KING, J. E. (2002). A history of Post Keynesian economics since 1936. Cheltenham, Northampton: Elgar.

KREGEL, J. A. (1976). Economic methodology in the face of uncertainty: the modeling methods of Keynes and the Post-Keynesians. The Economic Journal, 86, June.

KREGEL, J.A. (1980) Markets and Institutions as features of a capitalistic Production System. Journal of Post Keynesian Economics, 3(1) 32-48. 
KREGEL, J.A. (1983). Effective Demand: Origins and Development of the Notion. In Distribution, Effective Demand and International Economic Relations. London: Macmillan, pp: 50-68.

KREGEL, J. A. The multiplier and liquidity preference; two sides of the theory of effective demand. In Barrère, A. (ed.). The Foundation of Keynesian Analysis. New York: St Martin's Press, 1988.

KREGEL, J. A. (1997). The theory of value, expectations and chapter 17 of The General Theory. In HARCOURT \& RIACH (1997). A 'second edition' of The General Theory. London: Routledge.

LAVOIE, M. (1992). Foundations of Post-Keynesian Economic Analysis. Aldershot: Elgar

LAVOIE, M. (2006). Do Heterodox Theories Have Anything in Common? A Post-Keynesian Point of View. Journal of Economics, 3 (1), 87-112

LAVOIE, M. \& GODLEY, W. (2001-2002). Kaleckian Growth Models in a Stock and Flow Monetary Framework: A Kaldorian View. Journal of Post Keynesian Economics, 24(2), 277-312.

MACEDO E SILVA, A. C. (1995). A Economia de Keynes e a "armadilha do equilíbrio". Economia e Sociedade, 5, 1995, 111-159. Paper presented at the III Workshop on Post Keynesian Economics, Knoxville, Tennessee, United States, 1993.

MACEDO E SILVA, A. C. (1999). Macroeconomia sem equilíbrio. Rio de Janeiro: Vozes.

MACEDO E SILVA, A. C. (2007). Missing Details and Conspicuous Absences: from the Treatise to The General Theory. Journal of Post Keynesian Economics, forthcoming.

MANKIW, N. G. (1998). Macroeconomia. Rio de Janeiro: LTC.

MINSKY, H. P. (1975). John Maynard Keynes. New York: Columbia University Press.

MINSKY, H. P. (1986). Stabilizing an Unstable Economy. New Haven and London: Yale University Press.

MODIGLIANI, F. (1944). Liquidity Preference and the Theory of Interest and Money. In Lutz, F. A. e Mints, L. W. (orgs). Readings in Monetary Theory. Homewood: Richard D. Irwin, 1951.

PAPADIMITRIOU, D; SHAIKH, A; DOS SANTOS, C. \& ZEZZA, G. (2004). Is Deficit-Financed Growth Limited? Policies and prospects in an election year. Levy Economics Institute Strategic Analysis. Annandale-on-Hudson, NY

POSSAS, M. L. (1986). Para uma releitura teórica da Teoria Geral. Pesquisa e Planejamento Econômico, 16 (2), agosto, 295-308.

POSSAS, M. L. (1987). Dinâmica da Economia Capitalista: uma abordagem teórica. São Paulo: Brasiliense.

POSSAS, M. L. (1997). A Cheia do Mainstream. Comentário Sobre os Rumos da Ciência Econômica. Economia Contemporânea, Rio de Janeiro, v. 1, n. 1, p. 13-37.

ROBINSON, J. (1962). Essays in the theory of economic growth. London: Macmillan.

ROBINSON, J. (1978). Keynes and Ricardo. In What are the questions? and other essays - Further Contributions to Modern Economics. M. E. Sharpe, 1980.

ROBINSON, J. (1979). The generalization of the General Theory and other essays. London: Macmillan. SERRANO, F. (1995). Long period effective demand and the Sraffian Supermultiplier. Contributions to Political Economy, Vol.14. 67-90.

SKOTT, P. (1994). On the Modelling Systemic Financial Fragility. In A. Dutt (ed.), New Directions in Analytical Political Economy. Aldershot; Elgar, 1994.

SOLOW, R. (1956). A contribution to the theory of economic growth. Quarterly Journal of Economics, 70: $5-94$.

SOLOW, R. (1970/2000). Growth theory - an exposition. Oxford: Oxford University Press.

SOLOW, R. (1999) How cautious must the Fed be? In Solow, R. e Taylor, J.B. (1999) Inflation, Unemployment and Monetary Policy. Cambridge (Mass.): MIT Press.

SOLOW, R. (2000). Toward a Macroeconomics of the Medium Run. The Journal of Economic Perspectives, Vol. 14, No. 1, 151-158

STIGLITZ, J. \& WALSH, C. E. (2003). Introdução à macroeconomia. Rio de Janeiro: Campus.

TAYLOR, L. (1991). Income Distribution, Inflation and Growth. Cambridge, MA: MIT Press, 1991.

TAYLOR, L., and O'CONNELL, S. (1985). “A Minsky Crisis.” Quarterly Journal of Economics, 1985, 100 (Supplement), 871-885.

TOBIN, J. (1980). Asset Accumulation and Economic Activity. University of Chicago Press. 
TOBIN, J. (1982). Money and the Macroeconomic Process. Journal of Money, Credit and Banking, 14 (2), May, 171-204.

TOWNSHEND, H. (1937). Liquidity-Premium and the Theory of Value. Economic Journal, March, 157169.

WERNECK, R.L.F. (1987). Empresas Estatais e Política Macroeconômica. Rio de Janeiro: Campus. 